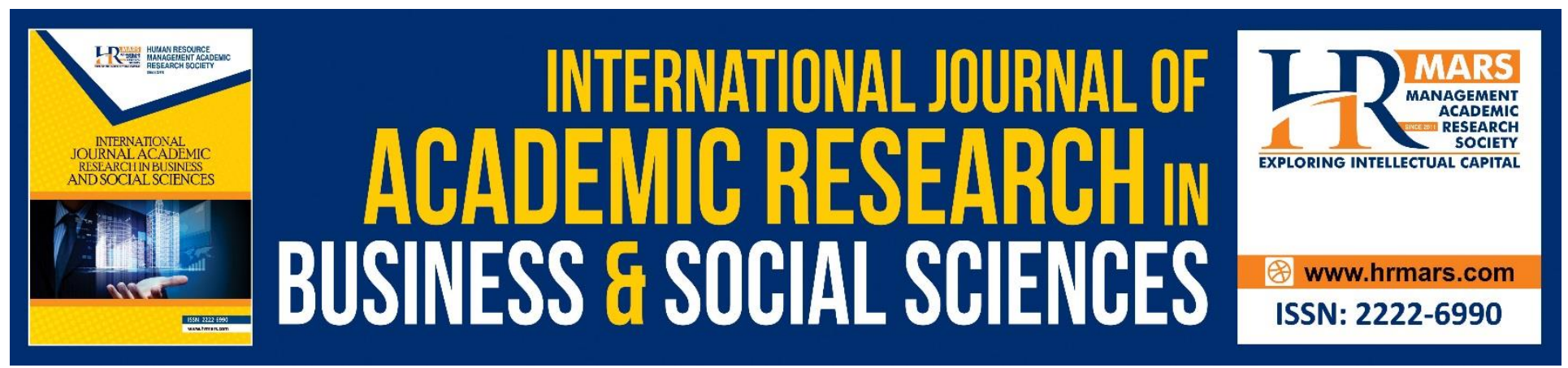

\title{
Roles of Arabic Language in Determination of Sunnah Corruption
}

\section{Muhammad Muthi ul Haqq Fatah Yasin \& Basri Ibrahim}

To Link this Article: http://dx.doi.org/10.6007/IJARBSS/v10-i9/7888

DOI:10.6007/IJARBSS/v10-i9/7888

Received: 04 June 2020, Revised: 10 July 2020, Accepted: 12 August 2020

Published Online: 27 September 2020

In-Text Citation: (Yasin, \& Ibrahim, 2020)

To Cite this Article: Yasin, M. M. H. F., \& Ibrahim, B. (2020). Roles of Arabic Language in Determination of Sunnah Corruption. International Journal of Academic Research in Business and Social Sciences. 10(9), 952-961.

Copyright: (c) 2020 The Author(s)

Published by Human Resource Management Academic Research Society (www.hrmars.com)

This article is published under the Creative Commons Attribution (CC BY 4.0) license. Anyone may reproduce, distribute, translate and create derivative works of this article (for both commercial and non-commercial purposes), subject to full attribution to the original publication and authors. The full terms of this license may be seen

at: http://creativecommons.org/licences/by/4.0/legalcode

Vol. 10, No. 9, 2020, Pg. 952 - 961

http://hrmars.com/index.php/pages/detail/IJARBSS

JOURNAL HOMEPAGE

Full Terms \& Conditions of access and use can be found at http://hrmars.com/index.php/pages/detail/publication-ethics 


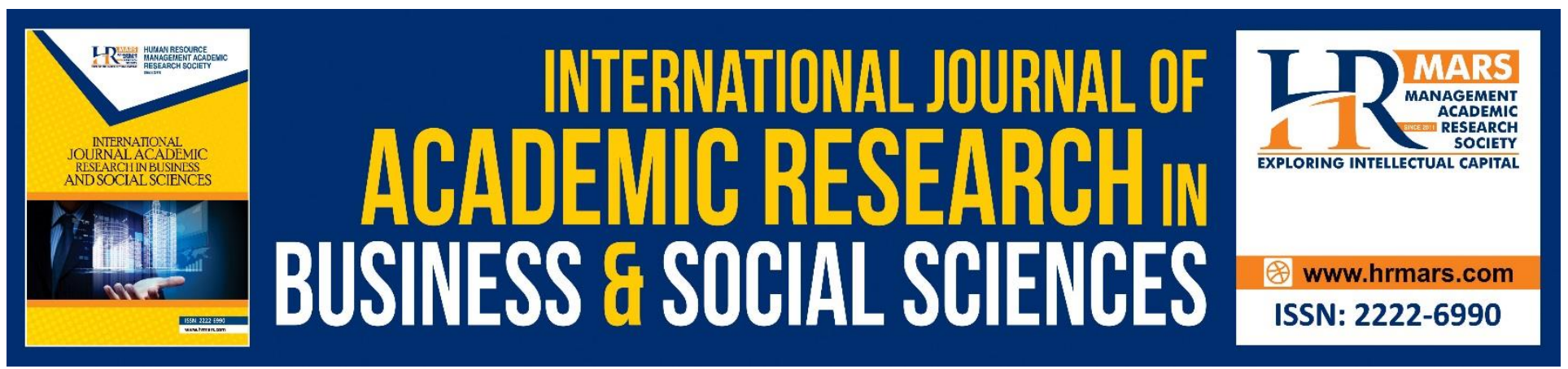

\title{
Roles of Arabic Language in Determination of Sunnah Corruption
}

\author{
Muhammad Muthi ${ }^{\prime}$ l Haqq Fatah Yasin ${ }^{1}$ \& Basri lbrahim² \\ ${ }^{1}$ University Islam Malaysia, Cyberjaya, Malaysia/ Kolej Universiti Islam Perlis, Perlis, Malaysia. \\ ${ }^{2}$ University Islam Malaysia, Cyberjaya, Malaysia/ Faculty Of Islamic Contemporary Studies, \\ University Sultan Zainal Abidin, Terengganu, Malaysia. \\ Email: muthi@kuips.edu.my
}

\begin{abstract}
Sunnah means words, actions, agreements and attributes referred to Rasulullah S.A.W. Authentic understanding of Sunnah needs a careful examination of meaning in literal and contextual aspect. Literal meaning can be recognised through Sunnah text without referring to reason of hadis revelation. Literal understanding of Sunnah text needs high Arabic language skills to avoid mistake in understanding Sunnah text and cause fraud upon Rasulullah S.A.W. From practical aspect, understanding literal meaning of Sunnah text needs mastery of Arabic language from three aspects which are meaning of words, meaning based on the words' position in the sentence and meaning of words according to situation. In this study, the researcher focused on the roles of Arabic language in determination of corruption to Sunnah mentioned in books of previous scholars. This study explains on corrupted understandings to Sunnah caused by mistakes in from Arabic language aspect whether intended or not. Method implemented in this study was qualitative method. Data were obtained based on document analysis by focusing on books related to Sunnah, Tauhid and Fiqh muktabar. Textual examination meanwhile was taken from books of Arabic language discipline related to knowledge of Șaraf, Naḥu and Balāghah. This study found that the main causes of corrupted understandings to appear is due to mistake in understanding Sunnah text from Arabic language aspect. From aspect of effect, ignorance of Arabic language in understanding Sunnah text causes the meaning to be wrongly concluded from the exact meaning and becomes the basis for corrupted understandings. As a conclusion, Arabic language skills are a need to determine mistakes occurring in understanding of Sunnah meaning.
\end{abstract}

Keywords: Sunnah, Arabic Language Role, Corruption.

\section{Introduction}

Arabic language is a language used to convey revelation to Rasulullah S.A.W. Descending of revelation in Arabic language becomes a sign of Allah S.W.T.'s greatness as mentioned in His words: 
INTERNATIONAL JOURNAL OF ACADEMIC RESEARCH IN BUSINESS AND SOCIAL SCIENCES Vol. 10, No. 9, 2020, E-ISSN: 2222-6990 @ 2020 HRMARS

Translation: Truly We descended the book as Quran read with Arabic language, that you may (use intellect to) understand it.

(al-Quran, 12: 2)

According to Ibn Kathir, descending of al-Quran in Arabic language is a sign of Allah S.W.T. greatness as Arabic language is a language of the clearest pronunciation, deepest meaning and the most effective to the soul of those who listen (Ibn-Kathir, 1419H.4:313). Ibn Kathir's view can be proved in the condition of people who recite al-Quran. People who recite al-Quran are in more peaceful condition compared to those who do not recite al-Quran as explained by al-Nabulsi (Nabulsi, 2009).

Advantage of Arabic language from literal aspect can be observed through change of meaning by minimal change of the diacritic. For example, words containing letter ta, 'ain, lam and $\mathrm{mim}$ if recited with diacritic ta'lam means you know, but if recited with diacritic tu'allim, it means you teach (Majma' al-Lughah al-'Arabiyyah, 2005: 624). Besides that, Arabic language also has its own melody posing psychological effect to human (al-'Aqqad, 2013: 11-13). This can be witnessed from words by al-Walīd bin al-Mughīrah while picturing the beauty of Quranic verses from Arabic language aspect:

Translation: Truly its words are sweet, above it is beauty, above it are fruits, beneath it (bounties) prosper, it is always in high position and there is nothing higher than it.

(al-Baihaqī: 532)

Role of Arabic language develops after arrival of Islam especially in the life of a Muslim. Arabic language becomes a part of Islamic symbols and applied in daily acts of worship such as recitation in the prayer, daily chanting and prayers. In Figh knowledge meanwhile, Arabic language skills become a basic need in understanding nas text to conclude from the text whether it is of obligatory, encouraged, neutral, disapproved or prohibited status. Weakness in Arabic language skills will bring to critical misunderstanding lead to deviation. Ibn Taimiyyah explained that the mistake in understanding Sunnah text comes from the weakness in Arabic language skills. This is because a person who does not master Arabic language will understand nas text from his own point of view that may not be comply with syarak need (Ibn-Taimiyyah, 1999. 1: 519).

The objective of this writing is to examine the roles of Arabic language in determination of Sunnah corruption. According to al-Syaikh, understanding of Ahli Sunnah wa al-Jamaah to Sunnah text does not differ much from those who master Arabic language well. Corrupted beliefs only appear and spread when Muslim community become weaker in understanding Arabic language thus causing them to accept the interpretations far from the exact meaning of Sunnah (al-Syaikh, 1430H: 3). Examples of corrupted beliefs to Sunnah due to Arabic language mistake are explained in this study.

Writings on the importance of mastering Arabic language were emphasised by past scholars and modern intellects, but the effects of weak Arabic language skills in understanding Sunnah are not elaborated in details and examples given are lacking. Among the writings by past scholars touching on the importance of Arabic language in understanding Sunnah are Gharib al-Hadith (al-Khattabi, 1982), Iqtida' al-Șirāṭ al-Mustaqīm (Ibn-Taimiyyah, 1999), Iḥkām al-Iḥkām Syarḥ 'Umdah al-Ahkām (Ibn-Daqiq, 1987) and al-Luma' Fi Ușūl al-Fiqh (al-Syairazi, 2003). Modern writings mentioning this 
INTERNATIONAL JOURNAL OF ACADEMIC RESEARCH IN BUSINESS AND SOCIAL SCIENCES

Vol. 10, No. 9, 2020, E-ISSN: 2222-6990 @ 2020 HRMARS

subject meanwhile are Dawābiț Fahm al-Sunnah al-Nabawiyyah (al-Syaikh, 1430H), Memahami Makna Hadis Secara Tekstual dan Kontekstual (Channa, 2011), Peranan Bahasa Arab Dalam Pengembangan IImu dan Peradaban Islam (Wahab, 2014) and Bahasa Arab dan Urgensinya Dalam Memahami al-Qur'an (Dewi, 2016).

\section{Methodology of Writing}

Writing methodology employed was based on qualitative research. Data were taken from books of hadis, Ulum hadis, Usul Fiqah and scholars' fatwa. Data collected were analysed and elaborated through inductive, deductive and comparative methods to gain suitable results in alignment with determined objectives.

\section{Findings}

Arabic language is important to understand Sunnah and it is agreed by scholars. Some scholars believe that the status of learning Arabic language is compulsory for a Muslim as the obligation of learning how to read al-Quran which is fardu ain. This is because al-Quran and Sunnah could not be comprehended in right context without mastering Arabic language in depth (Ibn-Taimiyyah, 1999, 1: 572). This has been explained since generation of Companions. Ubay bin Ka'ab R.A, said:

Translation: Learn Arabic language as you learn Quranic memorisation.

(Ibn-Abi-Syaibah: 29915)

Failure of mastering Arabic language will lead to mistakes in understanding sunnah text and conclusion of laws. This is stressed by al-Asmu'i explaining that people who narrate Sunnah without knowing Arabic grammar knowledge are feared to fall into those who lie upon Rasulullah S.A.W. (alKhattabi, 1: 63).

Awareness on the importance of mastering Arabic language in understanding Sunnah can also be witnessed when Ali bin Abi Talib R.A. commanded Abu al-Aswad al-Du'ali to arrange Arabic grammar knowledge. He realised the importance of compiling the knowledge as more non-Arabs embraced Islam and many mistakes occurred in speech. These mistakes even the small one would cause the next generation to not be able to understand the sources of laws which are al-Quran and Sunnah as understood by generation of Companions (al-Hasyimi, n.d.:5).

Besides that, the importance of Arabic language in understanding Sunnah can also be observed from aspect of Fiqh laws conclusion. Fiqh laws conclusion involves process of understanding Sunnah from varous aspects and can only be achieved by a Faqih (knowledgeable person) who masters Arabic language. This was visualised by al-Syafi' $i$ when he was asked by his son on why he dared to spend a duration of twenty years to learn Arabic language and History. Al-Syafi'i said:

Translation: Did not I perform that except to master Fiqh knowledge.

(al-Baghdadi, 1421H.2:41) 
INTERNATIONAL JOURNAL OF ACADEMIC RESEARCH IN BUSINESS AND SOCIAL SCIENCES Vol. 10, No. 9, 2020, E-ISSN: 2222-6990 @ 2020 HRMARS

Al-Syafi'i also resembled people who master Arabic language as djinns among human. This is because djinns are unseen creatures that can see things unseen by human. People who master Arabic language can see and understand nas from aspect uncrossed by minds of others (al-Razi, 2003: 112).

The above views provide conclusion that Arabic language is a basic subject in mastery of Islamic disciplines of knowledge. Realising the matter, past scholars had arranged branches of Arabic knowledge to ease next generations in understanding Arabic language and referring to sources of law especially Sunnah of Rasulullah S.A.W.

\section{Position of Arabic Language in Understanding Sunnah}

Arabic language knowledge has developed since early Islamic era by virtue of close relationship with Islamic religion itself. Scholars have arranged branches of Arabic language knowledge into three main parts. First, knowledge on change in words which is Soraf. Second, knowledge on sentence arrangement which is Nahu. Third, knowledge on deep and effective delivery of meaning which is Balaghah (al-Sakaki, 1987:6). In context of understanding Sunnah, basic knowledge of Arabic language needed can be divided into three main knowledge:

a. Knowledge on specific meaning of word. Arabic word is not only understood based on meaning in dictionary, but also depends on Arabic tribe who use the word. According to Ibn Taimiyyah, meaning of Arabic words mentioned in al-Quran and Sunnah and related to Islamic laws is divided into three. First, terms explained of their meaning clearly by syarak such as the word prayer, alms, fasting and pilgrimage. Second, terms understood of their meaning literally such as the word sun, moon and star. Third, terms understood based on community culture at that time such like the word sell, marriage, dirham and dinar (Ibn Taimiyyah (2), 1995. 19: 235).

b. Knowledge on the time when the word was used. Change of time causes change of word meaning. For example, the word syaitan (devil). Before arrival of Islam, this word means far from truth (Ibn al-Athir, 2: 475). After arrival of Islam, the word syaitan is understood by a different meaning which is Iblis and his descendants created from fire, making deception and creating hesitation in human's self (Tuqan, 1999: 468).

c. Knowledge on sentence context when a word is used. Sentence context in Arabic language is seen whether on the position of word in the sentence or the meaning to convey. Knowledge on the position of word in the sentence is termed as Nahu knowledge, which is a knowledge focusing on word from aspect of diacritic change at the end of word due to change of position in the sentence (al-Azharī, 1996. 1:11, 12). Knowledge on meaning to convey is termed as Balāghah knowledge, which is a knowledge focusing on method of delivering specific meaning to the listener effectively either through metaphor or other means (al-Qazwaynī, 2003:21, 22). Part of Sunnah of Rasulullah S.A.W. must be understood from contextual aspect and cannot be understood literally. For example, a Sunnah narrated by Abu Sa`îd al-Khudrī R.A., Rasulullah S.A.W. said: 
INTERNATIONAL JOURNAL OF ACADEMIC RESEARCH IN BUSINESS AND SOCIAL SCIENCES Vol. 10, No. 9, 2020, E-ISSN: 2222-6990 @ 2020 HRMARS

Translation: When someone of you approach his family and he wants to repeat it, then he must perform ablution.

(Muslim: 308)

The above hadis from literal aspect means when a man wants to meet his family member, he must perform ablution first. This understanding contradicts with the intended meaning. Rasulullah S.A.W. used the metaphor "approach his family" to refer to the action of having intercourse with wife. When a husband wants to repeat the action, he is encouraged by sunnah to perform ablution first (al-Nawawi, 1392H. 3:217).

\section{Corrupted Understandings to Sunnah}

Understanding Sunnah without viewing from Arabic language aspect could bring to wrong and deviated understanding. The importance of this can be observed in the interpretations of Sunnah among the figures of certain sects.

Corrupted understanding to nas has happened since the time of Rasulullah S.A.W. For example, the understanding on white thread and black thread as mentioned in words of Allah S.W.T.:

Translation: And eat and drink until it is clear for you the white thread from black thread, which is the dawn. Then complete the fasting until arrives (come) the night.

(al-Quran, 2: 187)

To understand the above verse, 'Adi bin Hatim R.A., said:

Translation: O Rasulullah, truly I put under my pillow two ropes; one white rope and one black rope to differentiate between night and day. Rasulullah S.A.W, said: Truly your settling place of head is wide. What is meant by the verse is (the transition between) darkness of night and brightness of day.

(al-Bukhari: 4509, Muslim: 1090)

'Adi bin Abi Hatim R.A, understood the meaning of white thread and black thread mentioned by Allah S.W.T. as the thread used for sewing. This understanding deviates from the real meaning of verse as the thread meant is a metaphor to transition between night and day where Rasulullah S.A.W. explained that thread in context of the above verse is the colour observable at the horizon when transition of night to day occurs (al-Bukhari: 4509, Muslim: 1090).

In context of Sunnah, this deviated understanding happens frequently in many hadis, among them is the understanding of the word tama'ninah in a hadis narrated by Abu Hurairah R.A., Rasulullah S.A.W. said to a man who did not perfect his prayer's action:

Translation: Then bow until you are in tama'ninah state.

(al-Bukhari: 757; Muslim: 397)

The word tama'ninah means sitting still until all joints sit in their appropriate place (Qal'aji \& Qunaibi, 1988: 293). Corrupted understanding for this word is quoted by Ibn 'Ābidīn that al-Jurjānī believed that the law for țama'ninah in prayer movement is sunat and not compulsory. Ibn 'Ābidīn 
INTERNATIONAL JOURNAL OF ACADEMIC RESEARCH IN BUSINESS AND SOCIAL SCIENCES Vol. 10, No. 9, 2020, E-ISSN: 2222-6990 @ 2020 HRMARS

rejected this opinion according to the above hadis where Rasulullah S.A.W. had commanded the man to repeat his prayer. If the law of tama'ninah in prayer movement is not compulsory, Rasulullah S.A.W. would only remark and did not command the man to repeat the prayer (Ibn-Ābidīn, 1992. 1:464).

The role of Arabic language in determination for corruption of understanding in the Sunnah above is observable in the statement by Ibn Taimiyyah in rejecting al-Jurjānī's opinion. He stressed that in the opinion, al-Jurjani ignored the meaning of bow and prostrate literally. According to him, both words literally does not only merely mean to bend and lower the body, indeed it also means to be in that position in calm state and without doing any other movement (Ibn-Taimiyyah (2), 1995. 22: 569).

The same situation occurred in Sunnah narrated by Ali R.A., he said:

Translation: When they (the Companions) heard Allah's name, they shake like the tree shakes during strong wind.

(al-Așbahānī, 1406H. 1: 76)

According to Isa, the above Sunnah becomes a strong evidence for permissibility of performing zikir in any condition and doing certain movements during zikir including doing zikir while dancing (Isa, 2007: 157). Isa's opinion is rejected by other scholars such as al-'Asqalani quoting alQurtubi's view that the law of doing zikir while dancing is prohibited according to majority of scholars (al-'Asqalani, 1379. 2: 442).

I's opinion is also refuted through argument from literal aspect. The word māda the above Sunnah literally means repeated movements from a direction to other direction either from right to left or from front to back (Ibn Manz̦ūr, 2003. 8: 410). This indicates that the Companions were in the same location while performing body movement for zikir such as people who perform a lot of zikir and also memorisers of al-Quran during Quranic recitation. This condition differs so much if compared to the dance that involves many movements and is not static at a position.

Corruption of understanding to Sunnah also happens due to understanding of word in Sunnah by the meaning understood not in the time of revelation. For example, a hadis narrated by Abu Hurairah R.A., Rasulullah S.A.W. said:

Translation: Five practices are included in fitrah: circumcision, shaving pubic hair, pulling armpit hair, cutting nails and thinning of moustache.

(al-Bukhari: 5889; Muslim: 49)

According to Ibn Daqiq, the word fitrah in the above hadis is interpreted as Sunnah. This causes scholars of Maliki sect opine that the law of circumcision is sunat. This law is summarised because Sunnah among Fiqh scholars means sunat. Ibn Daqiq emphasised that the above understanding deviates as the term Sunnah understood in the time of Rasulullah S.A.W. is the action, word or agreement by Rasulullah S.A.W. and is demanded of following by Muslim community either as compulsory or sunat. Usage of the term Sunnah by meaning of sunat did not occur during the time of Rasulullah S.A.W. and it only appeared during post-revelation era (Ibn-Daqiq, 1987. 1: 125, 126). 
INTERNATIONAL JOURNAL OF ACADEMIC RESEARCH IN BUSINESS AND SOCIAL SCIENCES Vol. 10, No. 9, 2020, E-ISSN: 2222-6990 @ 2020 HRMARS

Diacritic mistake in word also becomes the cause of corruption in understanding of Sunnah. This can be witnessed in a hadis narrated by Abu Bakar R.A., Rasulullah S.A.W. said:

Translation: What we left are alms.

(al-Bukhari: 3093; Muslim: 49)

Ahli Sunnah wa al-Jemaah narrated the word sadaqah in the above hadis with dhammah diacritic at the least letter. Dhammah diacritic at the last letter of the word sadaqah makes it as khabar (predicate) to the word 'what' ('Abd-al-Hamid, 1993: 91). Usage of the word sadaqah as khabar to the word 'what' means that the property left by Rasulullah S.A.W. could not be inherited by his descendants, but it should be given as alms to Muslim community who needed.

Syiah sect meanwhile narrates the above Sunnah by putting fathah diacritic at the last letter of the word sadaqah. Fathah diacritic at the last word makes it as maf'ul bih (the side who gets the effect of the other's action) to the word tarakna (we left) ('Abd al-Hamid, 1993: 128). Usage of the word sadaqah as maf'ul bih causes the word ma in the beginning of verse to mean 'no'. This change makes the meaning of the above Sunnah as the property left by Rasulullah S.A.W. could not be given as alms to Muslim community who needed, instead it should be given to his descendants (al-Syaikh, 1430H: 3).

\section{Conclusion}

Arabic language is implemented as the language of revelation, as the meaning delivered is deeper compared to other languages. Minimal change such as change of diacritic at the end of word is enough to change the total meaning of the sentence. Realising the close relationship between Arabic language and Islamic religion, scholars have arranged Arabic language knowledge concisely and make it as the main condition in conclusion of Fiqh laws. Conclusion of Figh laws meanwhile needs mastery of Arabic language to understand Sunnah in correct context as it becomes the second source of reference in Islam. Mastery of Arabic language is also important to determine mistake in text bringing to understanding corrupted and manipulated by irresponsible party to pose wrong understanding of Sunnah to the community.

Based on the above study, weakness in mastery of Arabic language causes the following negative impacts:

a. Wrong understanding to the meaning intended by religion from Sunnah text..

b. Mistake from Arabic grammatical aspect manipulated by certain sects to support their corrupted understanding.

c. Ignorance of Arabic language eases deviated sects to propagate their teachings.

d. Understanding word in Sunnah text without referring to the time of usage causes wrong conclusion of laws from Fiqh aspect. 
INTERNATIONAL JOURNAL OF ACADEMIC RESEARCH IN BUSINESS AND SOCIAL SCIENCES Vol. 10, No. 9, 2020, E-ISSN: 2222-6990 @ 2020 HRMARS

However, difference of Sunnah understanding in Fiqh field is khilaf muktabar as long as it does not breach basic principles in branches of Arabic language knowledge. This difference in understanding is only regarded as corrupted understanding if it touches faith aspect or bringing to Fiqh conclusion which is never mentioned by past scholars. In modern context, those who participate in Islamic agencies especially in fatwa field need to improve Arabic language skills from time to time. It is suggested that the government ensure that their Arabic language skills are at a satisfying level besides implementing Arabic language as compulsory course for Islamic studies program in higher learning institution in Malaysia.

Good mastery of Arabic language is expected to facilitate in constraining corrupted understandings especially from aspect of Sunnah text manipulation. Therefore, deeper researches are needed to investigate the effects of weakness in Arabic language mastery to understanding of Sunnah text and of how far the weakness contributes to deviated understandings in the world nowadays.

\section{Corresponding Author}

Muhammad Muthi'ul Haqq bin Fatah Yasin, University Islam Malaysia, Cyberjaya, Malaysia/ Kolej Universiti Islam Perlis, Perlis, Malaysia.

Email: muthi@kuips.edu.my.

\section{Acknowledgement}

Special thanks to the Majlis Agama Islam Dan Adat Istiadat Melayu Perlis for funding the research under Jamalullail Professorial Chair, Universiti Islam Malaysia.

\section{References}

'Abd -I-Hamid, M. M. (1993). al-Tuhfah al-Saniyyah. Beirut: al-Maktabah al-'Asriyyah.

'Abidat, T. A. (1999). 'Alam al-Jin Fi Du' al-Kitab wa al-Sunnah. $2^{\text {nd }}$ Ed. Riyad: Dar Isybilia.

Al- 'Aqqad, A. M. (2013). al-Lughah al-Sya'irah. Kaherah: Mu'assasah al-Hindawi.

al-'Absi, A. M. (1409H). Musannaf Ibn Abi Syaibah. Tahkik Kamal Yusuf al-Hut. Riyad: Maktabah alRasyid.

Al-'Asqalani, A. A. (1379H). Fath al-Bari. Beirut: Dar al-Ma'rifah.

Al-'Id, M. A. (1987) Ihkam al-Ihkam Syarh 'Umdah al-Ahkam. Tahkik: Ahmad Muhammad Syakir. Kaherah: Dar al-Kutub al-Salafiyyah.

Al-Ansari, M. M. (2003). Lisan al-'Arab. Kaherah: Dar al-Hadith.

Al-Asbahani, A. A. (1409H). Hilyah al-Awliya' Wa Tabaqat al-Asfiya'. Beirut: Dar al-Kutub al'Ilmiyyah.

Al-Azhari, K. A. (1996). Musil al-Tullab Ila Qawa'id al-I'rab. Tahkik 'Abd al-Karim Mujahid. Beirut: alRisalah.

Al-Baghdadi, A. A. (1421H). al-Faqih Wa al-Mutafaqqih. Tahkik: al-Gharazi. $2^{\text {nd }}$ Ed. Saudi: Dar Ibn alJawzi.

Al-Baihaqi, A. H. (1988). Dala'il al-Nubuwwah. Tahkik 'Abd al-Mu'ti Qal'aji. Beirut: Dar al-Kutub al'Ilmiyyah.

Al-Bukhari, M. I. (1422H). Sahih al-Bukhari. Tahkik Muhammad Zahir Nasir al-Nasir. Dar Tuq alNajah. 
INTERNATIONAL JOURNAL OF ACADEMIC RESEARCH IN BUSINESS AND SOCIAL SCIENCES

Vol. 10, No. 9, 2020, E-ISSN: 2222-6990 @ 2020 HRMARS

Al-Harani, A. A. H. (1995). Majmu' al-Fatawa. Tahkik: 'Abd al-Rahman bin Muhammad bin Qasim. Madinah: Majma' al-Malik Fahd.

Al-Harani, A. A. H. (1999). Iqtida' al-Sirat al-Mustaqim. Tahkik: Nasir 'Abd al-Karim al- 'Aql. $7^{\text {th }}$ Ed. Beirut: Dar 'Alam al-Kutub.

Al-Hasyimi, A. (n.d.) al-Qawa'id al-Asasiyyah Li al-Lughah al-'Arabiyyah. Beirut: Dar al-Fikr.

Al-Khattabi, H. M. (1982). Gharib al-Hadith. Tahkik 'Abd al-Karim Ibrahim al-Gharbawi. Damsyik: Dar al-Fikr.

Al-Nabulsi, M. R. (2009) Darurah Qira'ah al-Qur'an al-Karim Kulla Yawm. www.nabulsi.com.

Al-Nawawi, Y. S. (1392H). al-Minhaj Syarh Sahih Muslim bin al-Hajjaj. $2^{\text {nd }}$ Ed. Beirut: Dar Ihya' alTurath al-'Arabi.

Al-Naysaburi, M. H. (n.d.) Sahih Muslim. Tahkik Muhammad Fuad 'Abd al-Baqi. Beirut: Dar Ihya' alTurath al-'Arabi.

Al-Qazwayni, M. A. R. (2003). al-Idah Fi ‘Ulum al-Balaghah. Beirut: Dar al-Kutub al-IImiyyah.

Al-Qurasyi, I. U. (1419H). Tafsir al-Qur'an al-'Azim. Tahkik Muhammad Husain Syams al-Din. Beirut: Dar al-Kutub al-'Ilmiyyah.

Al-Razi, A. R. M. (2003). Adab al-Syafi'i Wa Manaqibuhu. Beirut: Dar al-Kutub al-'Ilmiyyah.

Al-Sakaki, Y. A. B. (1987). Miftah al-'Ulum. 2nd Ed. Beirut: Dar al-Kutub al-'Ilmiyyah.

Al-Syaibani, M. M. (1979). al-Nihayah Fi Gharib al-Hadith wa al-Athar. Tahkik Tahir Ahmad al-Zawi dan Mahmud Muhammad al-Tanahi. Beirut: al-Maktabah al-'Ilmiyyah.

Al-Syaikh, A. W. (1430H). Dawabit Fahm al-Sunnah al-Nabawiyyah. Riyad: Jami'ah al-Imam Muhammad bin Sa'ud.

Al-Syairazi, I. A. (2003). al-Luma' Fi Usul al-Fiqh. Beirut: Dar al-Kutub al-'Ilmiyyah.

Basmeih, A. M. (2013). Tafsir Pimpinan ar-Rahman. Kuala Lumpur: Jabatan Kemajuan Islam Malaysia (JAKIM).

Channa, A. W. L. (2011). Memahami Makna Hadis Secara Tekstual dan Kontekstual. Ulumuna Jurnal Studi Keislaman. Vol. XV. No. 2. December 2011. Mataram: Institut Agama Islam Negeri.

Dewi, I. S. (2016). Bahasa Arab Dan Urgensinya Dalam Memahami al-Qur'an. Kontemplasi Jurnal Ilmu-Ilmu Usuluddin. Vol. 4, No. 1. Tulungagung: Institut Agama Islam Negeri.

Isa, A. Q. (2007). Haqa'iq al-Tasawwuf. 16 ${ }^{\text {th }}$ Ed. Halab: Dar al-Ma'rifah.

Khairuldin, W. M. K. F. W., Hassan, S. A., Anas, W. N. I. W. N., Mokhtar, W. K. A. W., \& Embong, A. H. (2020). Al-Takyif Al-Fiqhi and its application in Islamic research methodology. Journal of Critical Reviews, 7(7), 462-467.

Muhbib, A. W. (2014). Peran Bahasa Arab Dalam Pengembangan Ilmu dan Peradaban Islam. Arabiyat Jurnal Pendidikan Bahasa Arab dan Kebahasaaraban. Vol. 1 No. 1 June 2014. Jakarta: Universitas Islam Negeri Syarif Hidayatullah.

Qal'aji, M. R., Qunaibi, H. S. (1988). Mu'jam Lughah al-Fuqaha'. $2^{\text {nd }}$ Ed. Dar al-Nafa'is. 